\title{
Introduction to glycopathology: the concept, the tools and the perspectives
}

\author{
Hans-Joachim Gabius ${ }^{*}$ and Klaus Kayser ${ }^{2}$
}

\begin{abstract}
Analyzing the flow of biological information is a fundamental challenge for basic sciences. The emerging results will then lend themselves to the development of new approaches for medical applications. Toward this end, the products of protein/lipid glycosylation deserve special attention. The covalent attachment of sugars to these carriers means much more than just a change of the carriers' physicochemical properties. In principle, the ubiquitous presence of glycoconjugates and the close inspection of the particular structural 'talents' of carbohydrates provide suggestive evidence for information coding by sugars. In fact, the theoretical number of 'words' (oligomers) formed by 'letters' (monosaccharides) is by far higher than by using nucleotides or amino acids. In other words, glycans harbor an unsurpassed coding capacity. The cyto- and histochemical detection of dynamic changes in the profile of cellular glycans (glycome, the equivalent of the proteome) by sugar receptors such as antibodies used as tools underscores the suitability of carbohydrates for such a task. The resulting staining patterns can be likened to a molecular fingerprint. By acting as ligand (counterreceptor) for endogenous receptors (tissue lectins), glycan epitopes become partners in a specific recognition pair, and the sugar-encoded information can then be translated into effects, e.g. in growth regulation. Of note, expression of both sides of such a pair, i.e. lectin and cognate glycan, can physiologically be orchestrated for optimal efficiency. Indeed, examples how to prevent autoimmune diseases by regulatory $T$ cells and restrict carcinoma growth by a tumor suppressor attest occurrence of co-regulation. In consequence, these glycans have potential to establish a new class of functional biomarkers, and mapping presence of their receptors is warranted. In this review, the cyto- and histochemical methods, which contribute to explore information storage and transfer within the sugar code, are described. This introduction to the toolbox is flanked by illustrating the application of each type of tool in histopathology, with focus on adhesion/growth-regulating galectins. Together with an introduction to fundamental principles of the sugar code, the review is designed to guide into this field and to inspire respective research efforts.
\end{abstract}

Virtual slides: The virtual slides for this article can be found here: http://www.diagnosticpathology.diagnomx.eu/vs/ 1670639891114983.

Keywords: Agglutinin, Glycobiology, Glycosylation, Lectin, Neoglycoconjugates

\section{Introduction}

Basic biochemistry teaches that the flow of biological information starts with transcription of genes, which code for proteins or RNA-based regulators of protein production. Both nucleotides and amino acids are linked to oligo- and polymers by the assembly-line production of linear chains. As shown in Figure 1a, b, this means that the only parameter varied in a respective biopolymer is the sequence of

\footnotetext{
* Correspondence: gabius@tiph.vetmed.uni-muenchen.de

${ }^{1}$ Chair of Physiological Chemistry, Faculty of Veterinary Medicine, Ludwig-Maximilians-University Munich, Veterinärstr 13, D-80539, Munich, Germany

Full list of author information is available at the end of the article
}

the building blocks. In consequence, the range of sequence permutations defines the coding capacity of these biomolecules. For a trimer, the natural set of four nucleotides will result in $64\left(4^{3}\right)$ isomers, the alphabet of 20 amino acids in $8000\left(20^{3}\right)$ tripeptides. For coding biological information in a minimum of space (such constraints become a major issue on cell surfaces, due to the requirement to present a wide array of signals), the coding capacity (number of distinct 'words' generated by the 'letters' of the respective alphabet) needs to reach far higher values. In molecular terms, one way toward this aim is to generate structural diversity beyond the sequence. How can this be accomplished 


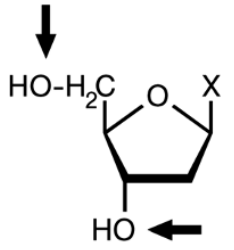

(a)

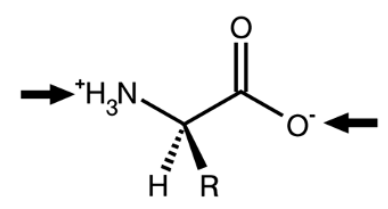

(b)

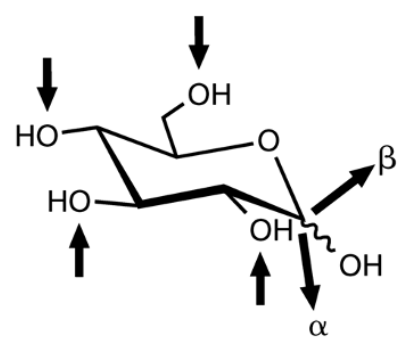

(c)

Figure 1 Illustration of the linkage points for oligomer formation in biomolecules by arrows. The phosphodiester bond in nucleic acid biosynthesis (a) and the peptide bond in protein biosynthesis (b) yield linear oligomers. In contrast, the glycosidic linkage in oligosaccharides can involve any hydroxyl group, opening the way to linear and also branched structures (c). Using D-glucose (Glc) as an example, its active form UDP-Glc allows conjugation of this sugar to carbohydrate acceptors to any hydroxyl group, as symbolized by arrows directed towards the hydroxy groups (for list of resulting diglucosides, please see Table 1). The anomeric position in chain elongation can vary, as symbolized by two bold arrows pointing away from the molecule (from [1], with permission).

by comparatively easy biochemistry, as realized in the cases of nucleic acids and proteins? Which type of biomolecule can meet this demand and also has the suited wide distribution in Nature? These questions will be answered in the next section by turning to biomolecules well-known for their capacity to store energy, i.e. the carbohydrates.

\section{Carbohydrates: the third alphabet of life}

A brief inspection of the structure of the most common sugar is enormously illuminating: $D$-Glucose (Glc) introduces the reader to i) the presentation of chemically rather equal hydroxyl groups for versatile formation of glycosidic linkages and ii) the principle of anomery, a type of isomery concerning the constellation at the anomeric center (the C1 atom) after ring formation (for details, please see Figure 2). As consequence, each hydroxyl group can be engaged as acceptor. Activation of a sugar at the anomeric center (here UDP-Glc) generates the donor, present in two anomeric constellations ( $\alpha$ or $\beta$ ). The site-specific coupling reaction is driven by a glycosyltransferase (for an illustration with $D$-Glc as example, please see Figure 1c) [1]. A resulting diglucoside therefore is not simply characterized as Glc-Glc as is the case for a dipeptide. Information on the anomeric character ( $\alpha$ or $\beta$ ) and the two connection points (theoretically possible are 1,$1 ; 1,2 ; 1,3 ; 1,4 ; 1,6$ ) is necessary for describing the individual disaccharide (to give an example, maltose is Glc $\alpha 1,4 \mathrm{Glc}$; for a listing of all naturally occurring diglucosides, please see Table 1 ).
In addition, as further sources of variability, the ring size (furanose or pyranose) can differ, branching of chains is possible and, like in proteins, substitutions (e.g. phosphorylation) can be introduced. Assuming an alphabet size of 20 for model calculations, the sugars (the third alphabet of life) can theoretically build $11.264 \times 10^{6}$ trimers, compared to $64 / 8000$ for the first (nucleotides) or second (amino acids) alphabets [2]. Even though the donor-acceptor biochemistry restricts the panel size, the comparison given in Figure 1 graphically documents the second-to-none capacity of carbohydrates for coding. Nonetheless, compared to the set of nucleotides and amino acids, less is commonly taught in biochemistry courses about the elements of the sugar alphabet.

In Nature, the sugar alphabet starts with Glc (building block of starch and cellulose, which differ in anomeric linkage type of the 1,4-connected units, highlighting the importance of seemingly small structural changes) and its 2'-derivative $\mathrm{N}$-acetyl-glucosamine (GlcNAc, unit of chitin) (Figure 3). These biomacromolecules actually are the most abundant polymers on earth (please see below). Epimers of Glc (a switch of a hydroxyl group from the energetically preferred equatorial to the axial position; please see the 4'-epimer galactose ( $\mathrm{Gal})$ and the 2'-epimer mannose (Man) in Figure 3), deoxy sugars, uronic acids and other anionic carbohydrates further belong to the sugar alphabet (Figure 3). Linking the 'letters' to 'words' will proceed without a genetic blueprint. Instead, factors such
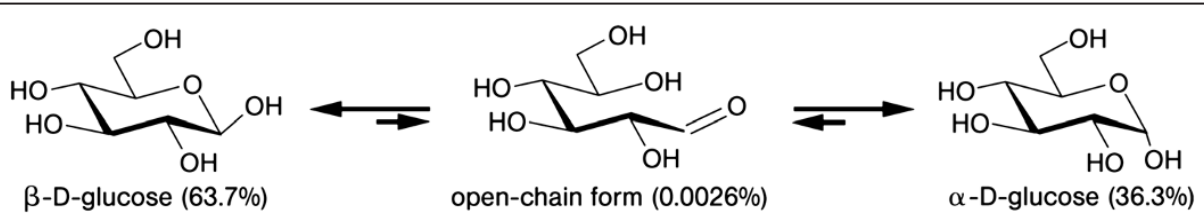

Figure 2 Illustration of the equilibrium including the two anomeric forms of D-glucose. The percentages of presence of the two anomeric hexopyranose and the open-chain forms in equilibrium are given in the bottom line (from [1], with permission). 
Table 1 Naturally occurring disaccharides formed from two glucose units

\begin{tabular}{ll}
\hline Type of linkage & Common name \\
\hline$a 1 \rightarrow 2$ & kojibiose \\
$\beta 1 \rightarrow 2$ & sophorose \\
$a 1 \rightarrow 3$ & nigerose \\
$\beta 1 \rightarrow 3$ & laminaribiose \\
$a 1 \rightarrow 4$ & maltose \\
$\beta 1 \rightarrow 4$ & cellobiose \\
$a 1 \rightarrow 6$ & isomaltose \\
$\beta 1 \rightarrow 6$ & gentiobiose \\
a1 $\rightarrow 1$ & trehalose \\
\hline
\end{tabular}

All disaccharides are conversion or degradation products of natural polysaccharides and glycosides, except for trehalose which is present in bacteria, fungi and insects; arrows depict involvement of anomeric centers (from [1], with permission). as substrate availability play into the product panel. The overall coding capacity in oligosaccharides is further enhanced, as for proteins, by introducing substitutions such as phosphorylation and sulfation (for physiologically prominent examples, please see Figure 4). In aggregate, the sugar alphabet, by virtue of the distinct chemical properties of sugars, enables enormous structural variability beyond the sequence: anomeric status, linkage formation involving different acceptor sites and ring size, with frequent occurrence of branching and site-specific presence of modifications, make this possible. Thus, the coding capacity of the sugar language is orders of magnitude higher than for nucleic acids and proteins.

Carbohydrate oligomers (glycans) or polymers (polysaccharides) are ubiquitous. Cellulose and chitin are the two most abundant organic compounds (with estimations for

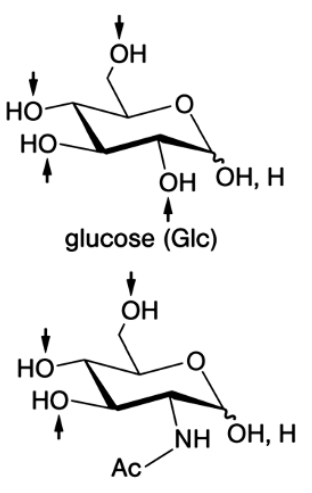

$\mathrm{N}$-acetylglucosamine (GlcNAc)

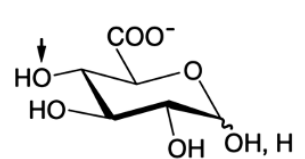

glucuronic acid (GlcA)

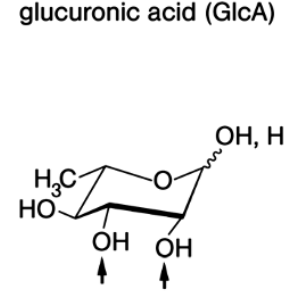

$\alpha$-L-rhamnose (Rha)
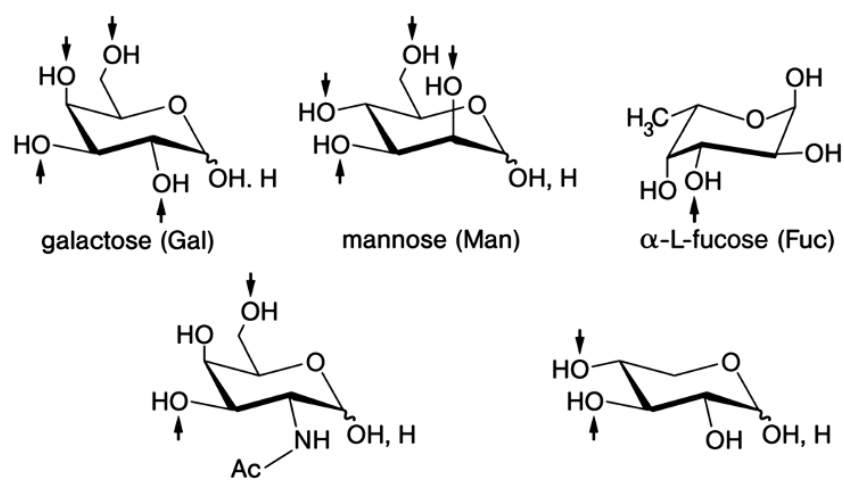

$\mathrm{N}$-acetylgalactosamine (GalNAc)

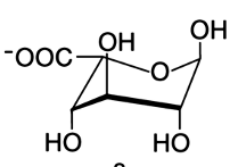

a

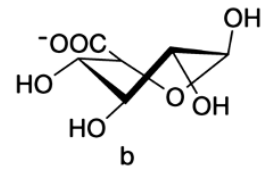

b

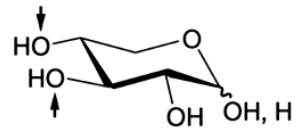

xylose (Xyl)

$\downarrow$

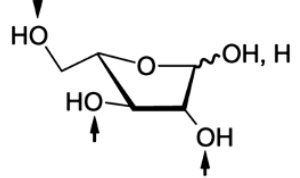

L-arabinose (Ara)

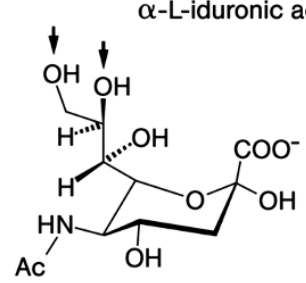<smiles>C[C@H]1C(O)[C@H](O)CC(O)(C(=O)[O-])C[C@H]1O</smiles>

$5-\mathrm{N}-$ acetyl- $\alpha-$ neuraminic acid (Neu5Ac)

2-keto-3-deoxy- $\alpha$-manno-octulosonic acid (Kdo)

Figure 3 Illustration of the alphabet of the sugar language. Structural representation, name and symbol as well as the set of known acceptor positions (arrows) in glycoconjugates are given for each letter. Four sugars have L-configuration: fucose (6-deoxy-L-galactose), rhamnose (6-deoxy-L-mannose) and arabinose are introduced during chain elongation, whereas L-iduronic acid (IdoA) results from post-synthetic epimerization of glucuronic acid at C-5. The ${ }^{1} C_{4}$ conformation of IdoA (a) is in equilibrium with the ${ }^{2} S_{O}$ form (b) in glycosaminoglycan chains where this uronic acid can be 2-sulfated (please see Figure 7d). All other "letters" are D-sugars. Neu5Ac, one of the more than 50 sialic acids, often terminates sugar chains in animal glycoconjugates. Kdo is a constituent of lipopolysaccharides in the cell walls of Gram-negative bacteria and is also found in cell wall polysaccharides of green algae and higher plants. Foreign to mammalian glycobiochemistry, microbial polysaccharides contain the furanose ring form of D-galactose and also D/L-arabinose indicated by an italic " $f^{\prime}$ derived from the heterocyclus furan. The a-anomer is prevalent for the pentose arabinose, e. g. in mycobacterial cell wall arabinogalactan and lipoarabinomannan. $\beta 1,5 / 6-$ Linked galactofuranoside is present in the arabinogalactan and the $\beta 1,3 / 6$ linkage in lipopolysaccharides (from [1], with permission). 


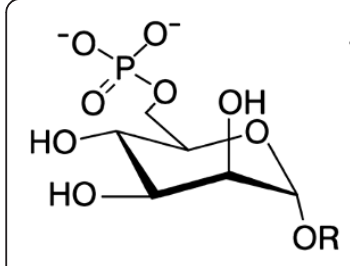

(a)

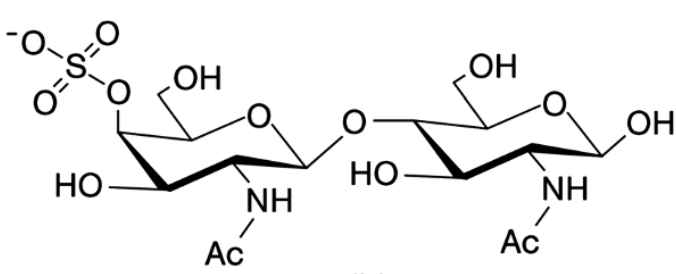

(b)

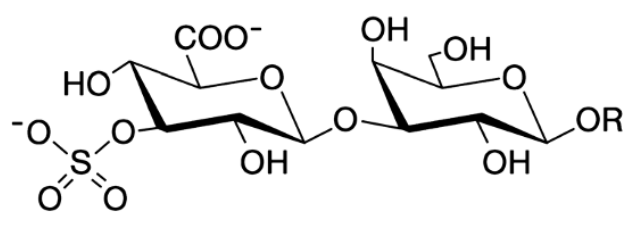

(c)

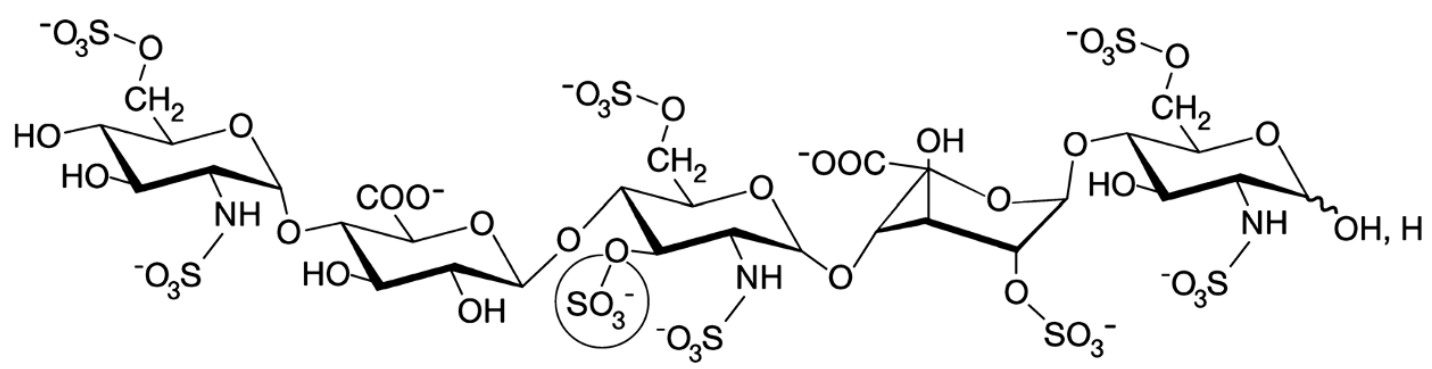

(d)

Figure 4 Illustration of phosphorylated (phosphated) and sulfated (sulfurylated) glycan "words". 6-Phosphorylation of a mannose moiety (in the context of a mannose-rich pentasaccharide) is the key section of a routing signal in lysosomal enzymes (a), 4-sulfation of the GalNAc $\beta 1,4 G$ IcNAc (LacdiNAc) epitope forms the "postal code" for clearance from circulation by hepatic endothelial cells of pituitary glycoprotein hormones labeled in such a way (b), the HNK-1 (human natural killer-1) epitope (3-sulfated GlcAß1,3Galß1,4GIcNAc) is involved in cell adhesion/ migration in the nervous system (c) and the encircled 3-O-sulfation in the pentasaccharide's center is essential for heparin's anti-coagulant activity (d). All sugars are in their pyranose form. Please note that the central glucosamine unit has N,O-trisulfation and that the 2-sulfated IdoA, given in the ${ }^{1} C_{4}$ conformation, can also adopt the hinge-like ${ }^{2} S_{0}$ skew-boat structure (please see Figure 3; about $60 \%$ or more for the ${ }^{2} S_{0}$ form in equilibrium depending on the structural context) when present within glycosaminoglycan chains of the proteoglycan heparin. 2-Sulfation of IdoA serves two purposes: favoring the hinge-like ${ }^{2} \mathrm{~S}_{O}$ conformation and precluding re-conversion to GlcA (from [1], with permission).

chitin production by animals reaching at least 10 gigatons) [3]. On eukaryotic cell surfaces, the glycan part of glycoconjugates (hybrid molecules of sugar and lipid/protein, termed glycoproteins/proteoglycan or glycolipid [4-8] is prominently positioned and readily accessible. The formation of at least 41 bonds between sugar and protein, with eight amino acids and 13 sugars involved, highlights the wide diversity of these types of conjugation in Nature [9]. Necessarily, an intricate enzymatic machinery for glycan assembly and remodeling (by glycosyltransferases, glycosidases and substitution-introducing enzymes such as sulfotransferases $[4-8,10])$ has developed to realize the actually presented set of glycans on cells (glycome) from the panel of theoretically possible glycans. In human cells, proteins destined for cell surface residence or secretion commonly carry glycan chains at the asparagine: Asn of the glycosylation sequon (Asn-X-Ser/Thr; $\mathrm{X} \neq \mathrm{Pro}$ ), the amide's nitrogen (N) acting as acceptor (thus the term N-glycosylation). But this high-level complexity in structure comes at a scientific price: "in this remarkable age of genomics, proteomics, and functional proteomics, I am often asked by my colleagues why glycobiology has apparently lagged so far behind the other fields. The simple answer is that glycoconjugates are much more complex, variegated, and difficult to study than proteins or nucleic acids" [11]. To address this problem and set the stage for full-scale glycome analysis led to development of sophisticated analytical procedures, even separating and identifying structural isomers reliably [12]. Their availability opens the door to comparative studies of glycan sequences in clinical specimens in the quest to define glycobiomarkers for diseases such as cancer, CA19-9 being an example [13-15].

In cyto- and histochemistry, the methods to detect glycan presence gained in specificity over time. Initially, carbohydrates were visualized by applying protocols like the PAS procedure (based on oxidizing vicinal hydroxyl groups of carbohydrates to reactive aldehydes) or stains such as Alcian blue (for glycosaminoglycans). These methods were replaced with marked increase in specificity by applying sugar receptors [16-21]. Known from transfusion medicine, certain antibodies are reactive with carbohydrate epitopes such as the blood group $\mathrm{ABH}$ determinants [22], and the monoclonal-antibody technology accounts for access to custom-made tools. The second class of sugar receptors used as laboratory tools 
for glycan detection are non-immunoglobulin agglutinins. They are referred to this way due to their capability to aggregate erythrocytes (haemagglutination) in a sugardependent manner [23,24]. These receptor proteins, separated from the class of antibodies and from enzymes, which process the bound sugar, are called lectins (for an overview on the history of lectinology starting with detection in snake venom and plant extracts, please see [25]). The large number of lectins from plants and invertebrates makes detailed monitoring of distinct glycome aspects possible, e.g. on status and type of sialylation or substitution of the core of N-glycans [16-21]. Especially these features are susceptible to changes upon altering genetic or microenvironmental parameters [26-28]. Sialylation can physiologically mask a glycan chain, the addition of the bisecting GlcNAc residue (a molecular 'wedge' between two glycan branches) or a fucose moiety to the N-glycan core is not a merely subtle structural difference. Instead, it is a molecular switch for the glycan's conformational dynamics, with important functional consequences during and after glycoprotein maturation [29-34]. What this popular method of specific detection of glycan epitopes also teaches is that these structures can serve as ligands (counterreceptors) in molecular recognition. Glycan detection by lectins (as tools) thus prompts the question on the presence of endogenous receptors, to read the sugar-encoded information and translate it into cellular responses.

\section{Lectins: translators of the sugar code}

The wide diversity of glycan structures in Nature let us expect an equally broad set of lectins. The diversity should concern both the number of families, defined by the folding pattern, and the number of members in each family. On the level of protein folds with capacity to bind sugars, this expectation is borne out: at least 14 types have developed in phylogenesis to endow animal/ human proteins with lectin activity (Table 2). Once established, each domain has undergone evolutionary diversification to generate a lectin family. This holds true for all cases listed in Table 2. Tracing the routes to diversity in individual families, e.g. C-type lectins and galectins, gives an impression on the ways sequences in the carbohydrate recognition domains (CRD) and their spatial modes of presentation can diverge including occurrence of single nucleotide polymorphisms in lectin genes [35-39]. Formation of non-covalent aggregates or the tandem-repeat display underlie the lectins' crosslinking capacity, depending on the presence of matching glycans. In this respect, the binding of lectins to their cellular targets markedly benefits from a special property of glycans: acquisition of only few energetically preferred conformers by limited flexibility [40,41]. In contrast, peptides will adopt certain conformations only when embedded into the context of a protein, otherwise be highly flexible. In other words, glycans often acquire key-like conformations. They are suited to be accommodated into a complementary binding site (CRD; molecular lock). This favorable factor for the thermodynamics of binding adds to the advantageous features of glycans in information coding outlined above.

Turning back to the protein side, genes for CRDs are widely disseminated in the genome. As integral part of many proteins, these domains can even be linked to other functional sites. This design leads to multifunctional proteins, e.g. collagen-like tails for aggregation in innate immunity lectins or cell- and carbohydratebinding sites in a slime mold lectin working together to effect ordered cell migration [43-45]. Evidently, homing in on distinct targets on bacterial surfaces or executing a certain task in guiding cells can take more than being able to bind a certain sugar. Intriguingly, lectin reactivity of glycoconjugates in their physiological context can be markedly modulated. In total, structural and topological factors of glycans on six levels cooperate to let lectins find their natural counterreceptors [41]. The attained specificity in target recognition lays the foundation for the spectrum of lectin functions compiled in Table 3. Exemplarily looking at routing/delivery processes, cargo selection and transport via lectins, e.g. of enzymes with the mannose-6-phosphate signal (Figure 4a) to lysosomes, glycoproteins with multiantennary $\mathrm{N}$-glycans to the apical side of polarized cells and of a cell adhesion molecule (L1) to axonal membranes [46-49], illustrate the reason why glycans are likened to a postal code. Orchestration of glycan/lectin expression goes far beyond transport processes.

In tumor biology, a deficiency in suppressor activity can cause the release from growth control. The study of reconstitution of activity of the tumor suppressor p16 $6^{\text {INK4a }}$ in vitro in pancreas carcinoma cells (Capan-1) has revealed the co-regulation of glycogenes (encoding several glycosyltransferases and two enzymes in sialic acid biosynthesis, a sugar at terminal positions regulating recognition [50]) with two distinct lectins (transcriptionally and post-transcriptionally) in order to make cells susceptible for lectin-dependent anoikis induction [51-53]. In detail, decreased synthesis of sialic acid reduces $\alpha 2,6$-sialylation on the cell surface, this in turn favoring binding and cross-linking of the fibronectin receptor ( $\alpha_{5} \beta_{1}$-integrin) by galectin- 1 and the ensuing activation of caspase-8 [51,53]. Expression of the physiological antagonist (galectin-3) is decreased for optimal cellular responsiveness to galectin-1. This homodimeric galectin is also the trigger element for growth regulation in other cases, with a different counterreceptor. Instead of a glycoprotein, binding of ganglioside GM1 in neuroblastoma cells and activated effector $\mathrm{T}$ cells, in both 
cases after enzymatic conversion of the precursor GD1a into the active counterreceptor by a sialidase [54-58], starts the regulatory cascade. The second sialic acid moiety of ganglioside GD1a (please see Figure 3 for structure of sialic acid) at its hexasaccharide terminus thus impairs the reactivity of the entire sugar chain of the ganglioside to preclude lectin recognition, its removal facilitating the binding to galectin-1.

Evidently, dynamic remodeling of glycans on the cell surface is an efficient means to let cells swiftly become responsive to distinct lectins, without the need for a complete neosynthesis. The specificity of counterreceptor recognition by tissue lectins guarantees correct reading of signals. As the in vitro examples indicate, lectins are expressed not only by normal cells but also in malignancy. Purification from extracts of tumor cells or tissue using affinity chromatography provides material for characterization and functional testing $[59,60]$. Given this expression of the glycobiological effectors in tumors, a new research area is opened, with the potential to identify a prognostic indicator and targets for therapy $[61,62]$. To test these assumptions, the developments of experimental approaches

Table 2 Overview of folds with capacity to bind sugars and of lectin classes

\begin{tabular}{|c|c|c|}
\hline Type of fold & Example for lectin & Example for ligand \\
\hline \multirow[t]{6}{*}{$\beta$-sandwich (jelly-roll) } & a) galectins & $\beta$-galactosides \\
\hline & b) calnexin, calreticulin & $\mathrm{Glc}_{1} \mathrm{Man}_{9} \mathrm{GlcNAC}_{2}$ \\
\hline & c) ERGIC-53, VIP36, VIPL & $\operatorname{Man}_{x} \mathrm{GlCNAC}_{2}$ \\
\hline & $\begin{array}{l}\text { d) } \mathrm{CRD}^{\mathrm{a}} \text { of Fbs1 in SCF E3 ubiquitin ligase and peptide-N- } \\
\text { glycanase }\end{array}$ & $\operatorname{Man}_{3} \mathrm{GlCNAC}_{2} ;$ mannopentaose \\
\hline & e) pentraxins & $\begin{array}{l}\text { glycosaminoglycans, MOßDG, 3-sulfated Gal, Gal- } \\
\text { NAc and GlcA, Man-6-phosphate }\end{array}$ \\
\hline & f) G-domains of the LNS family (laminin, agrin) & heparin \\
\hline C-type & asialoglycoprotein receptor, collectins, selectins & Fuc, Gal, GalNAc, Man, heparin tetrasaccharide \\
\hline I-type (lg fold) & N-CAM, TIM-3, siglecs & $\begin{array}{l}\text { Man }_{6} \mathrm{GlCNAC}_{2} \text {, HNK-1 epitope, a2,3/6-sialylated } \\
\text { glycans }\end{array}$ \\
\hline P-type & $\begin{array}{l}\text { mannose-6-phosphate receptors (MR) and proteins with } \\
\text { MR homology domain (erlectin, OS-9) }\end{array}$ & Man-6-phosphate, $\operatorname{Man}_{5,8} \mathrm{GlcNAC}_{2}$ \\
\hline \multirow[t]{4}{*}{$\beta$-trefoil } & a) fibroblast growth factors & heparan sulfate \\
\hline & $\begin{array}{l}\text { b) cysteine-rich domain of C-type macrophage mannose } \\
\text { receptor }\end{array}$ & GalNAc-4-sulfate in LacdiNAc \\
\hline & $\begin{array}{l}\text { c) lectin domain in GalNAc-Ts }{ }^{\mathrm{b}} \text { involved in mucin-type O- } \\
\text { glycosylation }\end{array}$ & GalNAC \\
\hline & $\begin{array}{l}\text { d) hemolytic lectin CEL-III of sea cucumber and lectin } \\
\text { EW29 of earthworm }\end{array}$ & Gal \\
\hline \multirow[t]{3}{*}{$\beta$-propeller } & a) 4-bladed: tachylectin-3 & S-type lipopolysaccharide GlcNAc/GalNAc \\
\hline & b) 5-bladed: tachylectin-2 & \\
\hline & c) 6-bladed: tachylectin-1 & KDO \\
\hline$\beta$-prism I & secretory proteins zg $16 \mathrm{p} / \mathrm{b}$ & Man, heparan sulfate \\
\hline$\beta$-prism ॥ & pufferfish (fugu) lectin & Man \\
\hline$\beta$-barrel with jelly-roll topology & tachylectin-4, eel (Anguilla anguilla) agglutinin, X-epilectin & Fuc \\
\hline \multirow[t]{4}{*}{ Fibrinogen-like domain } & a) ficolins & GlcNAC \\
\hline & b) intelectins (mammalian, Xenopus) & Galf, pentoses \\
\hline & c) tachylectin-5 & $\mathrm{N}$-acetylated sugars sialic acid \\
\hline & d) slug (Limax flavus) lectin & \\
\hline Link module & CD44, TSG-6, LYVE-1, aggregating proteoglycans & hyaluronic acid \\
\hline Hevein-like domain & $\begin{array}{l}\text { Tachycytin and spider (Selenocosmia huwena) neurotoxin; } \\
\text { cobra venom cardiotoxin }\end{array}$ & GalNAc; heparin-derived disaccharide \\
\hline $\begin{array}{l}(\beta / a)_{8} \text { barrel (glycoside hydrolase } \\
\text { family } 18)\end{array}$ & $\begin{array}{l}\text { YKL-40 (human cartilage glycoprotein-39; chitinase-like } \\
\text { lectin) }\end{array}$ & $(G \mid c N A c)_{n}$ \\
\hline $\begin{array}{l}\text { Short consensus repeat (complement } \\
\text { control protein module) }\end{array}$ & Factor $\mathrm{H}$ (complement regulator) & glycosaminoglycans, sialic acid \\
\hline
\end{tabular}

${ }^{\mathrm{a}}$ carbohydrate recognition domain, ${ }^{\mathrm{b}} \mathrm{N}$-acetylgalactosaminyltransferases; adapted from [42], with permission. 
Table 3 Functions of animal and human lectins ${ }^{a}$

\section{Activity}

Recognition of stem region of $\mathrm{N}$-glycans, a signal for ubiquitin conjugation when accessible in

incorrectly folded glycoproteins

Molecular chaperones with dual specificity for $\mathrm{Gl}_{2} / \mathrm{Gl}_{1} \mathrm{Man}_{9} \mathrm{GlcNAc}_{2}$ and protein part of nascen glycoproteins in the ER

Targeting of misfolded glycoproteins with $\mathrm{Man}_{8-5} \mathrm{GlCNAC}_{2}$ as carbohydrate ligand to ER-associated degradation (ERAD)

Intracellular routing of glycoproteins and vesicles and apical delivery

Intracellular transport and extracellular assembly

Enamel formation and biomineralization

Inducer of membrane superimposition and zippering (formation of Birbeck granules)

Cell type-specific endocytosis

Recognition of foreign glycans ( $\beta 1,3$-glucans, cell wall peptidoglycan, $\operatorname{LOS}^{\mathrm{n}}$ and $\mathrm{LPS}^{\circ}$ ),

mycobacterial glycolipid or host-like epitopes

Recognition of foreign or aberrant glycosignatures on cells (including endocytosis or initiation of opsonization or complement activation) and of apoptotic/necrotic cells (glycans or peptide

motifs)

Targeting of enzymatic activity in multimodular proteins

Bridging of molecules

Induction or suppression of effector release $\left(\mathrm{H}_{2} \mathrm{O}_{2}\right.$, cytokines etc.)

Alteration of enzymatic activities in modular proteins/receptor endocytosis via lattice formation Cell growth control, induction of apoptosis/anoikis and axonal regeneration

Cell migration and routing

Cell-cell interactions

\section{Example of lectin}

$\mathrm{F}$-box proteins Fbs1 and Fbs2, which comprise the ligand-specific part of $\mathrm{SCF}^{\mathrm{b}}$ ubiquitin ligase complexes

Malectin/ribophorin I complex, calnexin, calreticulin

EDEM1,2 $2^{\mathrm{C}} / \mathrm{Mnl} 1$ ( $\mathrm{Htm} 1$ ) (lectins or glycosidases?), Yos9p (MRH ${ }^{\mathrm{d}}$ domain) in yeast, erlectin (XTP3-B $\mathrm{B}^{\mathrm{e}}$ ) and OS-9f in mammals

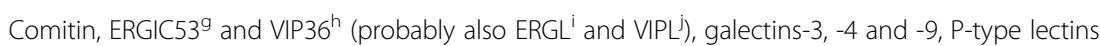
Non-integrin 67 kDa elastin/laminin-binding protein

Amelogenin

Langerin (CD207)

Cysteine-rich domain ( $\beta$-trefoil) of the dimeric form of mannose receptor for GalNAc-4-SO $\mathrm{S}_{4}$-bearing glycoprotein hormones in hepatic endothelial cells, dendritic cell and macrophage C-type lectins (mannose receptor family

members (tandem-repeat type) and single-CRD ${ }^{k}$ lectins such as trimeric langerin/CD207 or tetrameric DC-SIGN'/CD209), hepatic and macrophage asialoglycoprotein receptors, HAREm, , P-type lectins

$\mathrm{CR}^{\mathrm{P}}$ (CD11b/CD18, Mac-1 antigen), C-type lectins such as collectins, DC-SIGN, dectin-1, Mincle and Regllly (murine) $)^{q}$ or HIP/PAP (human), ficolins, galectins, immulectins, intelectins, Limulus coagulation factors $C$ and $G$, siglecs, tachylectins

Collectins, C-type macrophage and dendritic cell lectins, CR3 (CD11b/CD18, Mac-1 antigen), a/ $\Theta-$ defensins, ficolins, galectins, pentraxins (CRP, limulin), Regllly (HIP/PAP), siglecs, tachylectins

Acrosin, Limulus coagulation factor C, laforin, $\beta$-trefoil fold ((QxW) 3 domain) of GalNAc-Ts ${ }^{r}$ involved in mucin-type O-glycosylation, frequent in microbial glycosylhydrolases for plant cell wall polysaccharides, termed carbohydrate-binding modules

Cerebellar soluble lectin, cytokines (e.g. IL-2 $2^{5}-\mathrm{IL}-2 \mathrm{R}$ and CD3 of TCR), galectins

Chitinase-like YKL-40, galectins, I-type lectins (e.g. CD33 (siglec-3), siglecs-7 and -9), selectins and other C-type lectins such as CD23, BDCA2 and dectin-1, Toll-like receptor 4

Mannan-binding lectin (acting on meprins); galectins

Amphoterin and other heparin-binding proteins, cerebellar soluble lectin, chitinase-like lectins, Ctype lectins, galectins, hyaluronic acid-binding proteins, siglecs (e.g. CD22 and CD33)

Galectins, hyaluronic acid-binding proteins (CD44, hyalectans/lecticans, RHAMM ${ }^{t}$ ), I-type lectins, selectins and other C-type lectins

Galectins, gliolectin, I-type lectins (e.g. siglecs, N-CAM ${ }^{4}, \mathrm{P}_{0}$ or L1), selectins and other C-type lectins such as DC-SIGN or macrophage mannose recepto 
Table 3 Functions of animal and human lectins ${ }^{a}$ (Continued)

Cell-matrix interactions

Calreticulin, discoidin I, galectins, heparin- and hyaluronic acid-binding lectins including hyalectans/ lecticans

Matrix network assembly

Galectins (e.g. galectin-3/hensin), non-integrin $67 \mathrm{kDa}$ elastin/laminin-binding protein, proteoglycan core proteins (C-type CRD and G1 domain of hyalectans/lecticans)

adapted from [42], with permission, and extended.

Skp-1-Cul1-F-box protein complex.

${ }^{C} E R$ degradation enhancing a-mannosidase-like protein

${ }^{d}$ mannose-6-phosphate receptor homology.

eXTP3-transactivated gene B precursor.

fosteosarcoma 9.

${ }^{9}$ ER-Golgi intermediate compartment protein (lectin) (MW: $53 \mathrm{kDa}$ ).

${ }^{h}$ vesicular-integral (membrane) protein (lectin) (MW: $36 \mathrm{kDa}$ ).

'ERGIC-53-like protein.

jVIP-36-like protein.

kcarbohydrate recognition domain.

Idendritic cell-specific ICAM-3-grabbing nonintegrin.

mendric cell-specific ICAM-3-grabbing n

hyaluronan receptor for endocytosis.

nlipooligosaccharide.

Pcomplement receptor type 3.

${ }^{9}$ complement receptor type 3 .

'UDP-GalNAc:polypeptide $N$-acetylgalactosaminyltransferases.

${ }^{t}$ receptor for hyaluronan-mediated motility.

uneural cell adhesion molecule. 
to detect lectin presence (alone and embedded in a network) and the expression of binding partners - in view of the mentioned cases for orchestration of both sides of this recognition system - are the central challenges. They are mastered by strategic combination of chemistry and biochemistry, adapted to cyto- and histochemistry.

\section{How to detect tissue lectins}

Having described glycans as information-bearing biomolecules and plant/invertebrate lectins as tools to characterize the cellular glycophenotype and disease-associated alteration (please see first section in Table 4), the principle to follow for the design of lectin-detecting probes is rather obvious: use glycans in search of binding sites (CRDs). Products from chemical synthesis of oligosaccharides (for an introduction into this field, please see [63]) or from purification from natural sources such as glycoproteins can fulfill any request for product specifications. Next, the issues of turning glycans into high-affintiy binders and of introducing a label are addressed. As the natural role model for glycan presentation in clusters teaches, the conjugation of a carbohydrate derivative to a scaffold (protein or synthetic polymer) is a suitable strategy to achieve the affinity increase. This synthetic attachment leads to neoglycoproteins/neoglycoconjugates (the prefix neo describing the synthetic origin), with the expected enhancement of lectin reactivity when moving from mono- to polyvalency [64-67]. Having prepared the conjugate, introducing a label is the final step of the synthetic scheme. A natural mode of labeling is the association of glycan presentation with an enzymatic activity, e.g. in alkaline phosphatase or horseradish peroxidase [68-70]. This principle can be adopted by preparing enzymeneoglycoprotein conjugates or neoglycoenzymes [71,72]. Of note, the reactivity of the high-mannose-type $\mathrm{N}$ glycans of the plant peroxidase, a component of staining kits, with mannose-specific lectins in situ, e.g. the C-type tandem-repeat-type receptor on macrophages, gives reason to perform rigorous controls for specificity to exclude a false-positive outcome in cyto- and histochemical processing.
In general, chemistry facilitates to introduce any label such as biotin or fluorescent dyes into the scaffold to let the neoglycoconjugates enter routine practice. This approach is referred to as glycocyto- and histochemistry (please see second section in Table 4). Unless receptors are blocked by their engagement with high-affinity tissue sites or harmed by processing steps such as fixation, presence of carbohydrate-binding proteins can then be comprehensively studied. Using the same type of scaffold and label, in combination with stringent controls (testing carbohydrate-free scaffold and running inhibition assays), will enable a cell/tissue profiling of capacity to bind carbohydrate epitopes. Histopathologic application of these tools not only ascertained the validity of the concept but also indicated the potential to distinguish cell/tumor types [74-77]. At $95 \%$ sensitivity $/ 72 \%$ specificity binding of the pentasaccharide of ganglioside GM1 (mentioned above as galectin-1 counterreceptor) occurred to mesothelioma [78], and GalNAc binding was different between sections of typical and atypical carcinoid tumors of the lung [79]. Using the strategic combination of carbohydrate chemistry to synthesize biologically relevant di- and oligosaccharides, e.g. the Thomsen-Friedenreich $(\mathrm{T})$ antigen or histo-blood group determinants, with glycohistochemistry answered the question positively for tissue presence of respective receptors, e.g. in breast and lung cancer [80,81]. Based on analysis of 187 lung cancer cases a favorable prognostic correlation was discerned for binding of the histo-blood group $\mathrm{A}$ and $\mathrm{H}$ (but not B) trisaccharides [81]. In this respect, members of the family of galectins (galactoside-binding $\beta$-sandwichfold proteins with a sequence signature prominently harboring a $\operatorname{Trp}$ moiety responsible for contact to the Gal-moiety of cognate glycans [38]) are candidate receptors, owing to their involvement in growth processes and the known reactivity to these epitopes $[82,83]$. Thus, results from glycocyto- and histochemistry give direction for the next step to take in analyzing the glycan-based communication, i.e. to purify the tissue lectins and work with lectin-specific antibodies (please see third section in Table 4), here illustrated exemplarily for galectins as example.

Table 4 The four classes of reagents used in glycocyto- and histochemical analysis

\begin{tabular}{|c|c|c|}
\hline Experimental aim & Type of reagent & Example \\
\hline Detect certain aspects of glycosylation & $\begin{array}{l}\text { Plant lectin/carbohydrate- } \\
\text { specific antibody }\end{array}$ & $\begin{array}{l}\text { Monitoring the presence of } \beta 1,6 \text {-branching in N-glycans or of sialylated } \\
\text { Lewis epitopes }\end{array}$ \\
\hline $\begin{array}{l}\text { Detect accessible sites binding a distinct } \\
\text { carbohydrate epitope }\end{array}$ & Neoglycoconjugate & Detecting binding sites for sialylated Lewis epitopes in colon cancer \\
\hline Detect distinct lectins in situ & $\begin{array}{l}\text { Antibody specific for } \\
\text { endogenous lectin }\end{array}$ & $\begin{array}{l}\text { Performing immunohistochemical galectin fingerprinting in colon cancer } \\
\text { (with prognostic relevance for galectins) }\end{array}$ \\
\hline $\begin{array}{l}\text { Detect accessible ligands (glycan/peptide) } \\
\text { for an endogenous lectin }\end{array}$ & Tissue lectin & $\begin{array}{l}\text { Delineating prognostic relevance for galectin-3 binding in head and neck } \\
\text { cancer sections }\end{array}$ \\
\hline
\end{tabular}

From [73], with permission. 


\section{The galectin network in tumors}

Following the directives given above, sugar-specific staining guides selection of the resin-bound ligand for affinity chromatographic purification of proteins(s) with respective specificity. Glycohistochemical monitoring is thus more than a screening. The strong staining intensity specific for $\beta$ galactosides (of neoglycoproteins bearing lactose or glycoproteins after sialic acid removal from the glycan chains) in muscle biopsy specimens (itself of diagnostic value in fiber typing on fixed material [84]) prompted lectin purification using a resin presenting lactose and raising lectin-specific antibodies with the protein now termed galectin-1. The ensuing immunohistochemical work revealed the expectable similarity between the glyco- and immunohistochemical staining patterns [84]. The $\mathrm{Ca}^{2+}$-independent tissue reactivity to lactose moieties or the $\mathrm{N}$-acetyllactosamine terminus of N-glycan chains of asialofetuin is thus attributable to galectin-1, the most prevalent member of this lectin family in muscle (mentioned above as potent growth regulator), and galectins are also found in tumors. Reflecting the apparent diversification of the ancestral gene in this lectin family [35,38], more than one galectin can be expressed in tumors, initially documented by histopathology using non-crossreactive antibodies in breast cancer [85]. Of course, the localization profiles can differ, and parameters such as degree of differentiation can affect the results to non-identical extents for the proteins tested. Consequently, galectin fingerprinting with non-crossreactive antibodies, and not a focus on a single family member, is advisable to get a clear view on effector presence.

Respective studies on colon and on head and neck cancer as well as bladder carcinoma went beyond underscoring the network concept by disclosing prognostic relevance for distinct family members, e.g. galectins- 1 and -4 in colon cancer [86,87], galectin-7 in hypopharyngeal cancer $[88,89]$ as well as galectins- 2 and -8 in urothelial carcinoma [90]. Moreover, differential diagnosis and celllineage characterization are aided by this fingerprinting [91,92]. Combined with syntactic structure analysis, which assesses cell distribution relative to staining parameters for tumor/inflammatory cells including measuring structural entropy (for methodological details, please see $[93,94]$ ), further prognostic indicators can be delineated. Distances between tumor cells (positivity for galectin- 8 at high intensity) and lymphocytes as well as between galectin-1-positive tumor cells were of prognostic relevance in testicular cancer patients with lung metastases [95]. To avoid falsenegative results in such studies, special attention should be given to the possibility for in situ processing of a galectin and the appropriate selection of the antibody: proteolytic truncation by matrix metalloproteinases -2 and -9 of galectin-3's N-terminal tail can remove the antigenic epitope from the lectin and hereby be the reason for making the lectin invisible.
Two lines of experimental evidence guide from this fingerprinting to the next methodological step: i) the glycophenotype analysis with plant lectins and ii) the functional correlation between receptor (lectin)/counterreceptor (glycan) expression, as outlined above, both encourage to test tissue lectins as tools. After having paved the way to these proteins in sufficient quantities by recombinant expression, galectin cyto- and histochemistry could be realized (please see fourth section in Table 4). As plant agglutinins, human lectins can readily be labeled, under activity-preserving conditions, and then employed to trace reactive sites in cells, in different types of specimens [96-101]. In tumor pathology, galectins-3 binding proved of prognostic relevance in colon and advanced laryngeal/hypopharyngeal cancer [102,103]. Interestingly, a modification of the lectin, e.g. by altering structural parameters relevant for stability or clearance $[104,105]$, is not neutral but can change binding properties or harm activity. Combining the monitoring of distinct characteristics of the glycophenotype such as the status of $\alpha 2,6$-sialylation with measuring presence of galectins and their reactivity, as performed for colon cancer $[28,86,87,103]$, along with monitoring of functionally relevant gene products such as the fibronectin receptor ( $\alpha_{5} \beta_{1}$-integrin), a galectin counterreceptor in carcinoma growth regulation via cell cycle arrest or anoikis induction $[51,106,107]$, has potential to take mapping of epitope presence to function-oriented analysis. Similarly, galectin expression along with its apoptosis-inducing counterreceptor CD7 explains the clonal selection toward $\mathrm{CD}^{+} \mathrm{CD}^{-} \mathrm{T}$ leukemic cells during progression of the Sézary syndrome [108]. The presented principles underlying the glyco- and galectin cyto- and histochemical approaches are not only instrumental for the glycobiological aspect of specimen characterization. They also have relevance beyond studying glycobiological effector pathways. Examples inspiring further applications will be given in the next section.

\section{Carrier-immobilized/free ligands tracing their receptors}

The localization of galectins by labeled (neo)glycoconjugates documents maintained capacity for specific binding even after fixation of the specimen and its exposure to organic solvents. If this prerequisite is fulfilled for a receptor, more types of natural ligands can serve the purpose to track down presence of accessible binding sites. In the first step, a conjugation to a labeled scaffold without impairing the ligand activity is performed. Using estradiol and testosterone, attached to albumin as inert carrier, presence of steroid hormone receptors was detected in tissue sections of lung cancer and in pleural effusion of mesothelioma, here with relation to the $\mathrm{S}$-phase-related tumor cell fraction $[109,110]$. When similarly presented by a carrier, anthracylin reactivity was revealed in sections of small cell lung cancer sections, with prognostic relevance [111]. In 
addition to the information obtained by the staining reaction, positivity also is an incentive for biochemical work to determine the nature of binding sites for the scaffoldpresented ligands, the case study on galectin isolation from muscle mentioned above.

Mimicking the (ga)lectin histochemical approach of glycan profiling, any protein is suited for localization of binding partners, if labeling does not harm the interaction with counterreceptor(s). To achieve localization biotinylation by signal generation has been found applicable for interleukin-2 [112,113], erythropoietin [114], the epidermal growth factor $[115,116]$, macrophage migration inhibitory factor, with prognostic relevance in carcinoid tumors of the lung [79], and sarcolectin interacting with this broad-spectrum pro-inflammatory cytokine $[81,117,118]$. In order to select the least activity-reducing type of modification for labeling, systematic study of the influence of amino acid modification with group-specific reagents on the interaction is advised. In principle, this approach extends the scope of immunohistochemical localization, especially in cases when a ligand can bind to several distinct receptors or when characterizing the range of interaction partners has not yet been taken to the biochemical level.

\section{Conclusions}

Carbohydrates can form oligo- and polymers, with equally wide distribution as that of nucleic acids and proteins. Biochemically, they are more than fuel or concrete for cell walls. The consideration of the chemical properties of sugars explains their amazing capacity to turn the 'letters' of this alphabet (monosaccharides) into an unsurpassably large array of 'words'. While being central to the enormous versatility of sugar-based coding, this structural complexity poses an extraordinary challenge for compound analysis, much greater than for any other class of biopolymer. Fittingly, respective methods have become available only recently. Physiologically, the molecular meaning of cellular glycan determinants can be translated into responses by receptors (lectins). Evidently, the glycophenotype of cells has a functional dimension, nourishing the expectations for biomedical relevance of its characterization.

Based on the concept of the sugar code outlined above four technical approaches enable histopathologists to define respective aspects cyto-and histochemically:

1. Glycan profiling by carbohydrate-specific antibodies or plant/invertebrate lectins

2. Profiling of carbohydrate-binding sites by (neo) glycoconjugates

3. Immunohistochemical detection of lectins and fingerprinting for family members in an emerging network

4. Profiling cognate sites by endogenous lectins (in combination with 3. enabling colocalization)
Taking this step-by-step approach is currently revealing correlations between clinical and glycopathological parameters, encouraging further efforts. Work in vitro substantiates the assumed effector functionality of lectins by targeting distinct counterreceptors such as an integrin, an adhesion molecule or a ganglioside. These findings in turn inspire further investigations on clinical specimens. For monitoring serum samples, the lectinreactive clycans of the cellular clycoconjugate(s) then can become functional glycobiomarkers. Of note, the approach with carrier-immobilized ligands and labeled receptor proteins (here lectins) can find application for epitope-specific localization studies beyond glycopathology.

\section{Competing interests}

The authors declare that they have no competing interests.

\section{Authors' contribution}

HJG and KK shared work on design and preparation of the review. Both authors read and approved the final manuscript.

\section{Acknowledgements}

The generous funding from the EC Seventh Framework Program under grant agreements No. 2602600 (GlycoHIT) and no. 317297 (GLYCOPHARM) and from the Verein zur Förderung des biologisch-technologischen Fortschritts in der Medizin e.V. is gratefully acknowledged.

\section{Author details}

${ }^{1}$ Chair of Physiological Chemistry, Faculty of Veterinary Medicine, Ludwig-Maximilians-University Munich, Veterinärstr 13, D-80539, Munich, Germany. ${ }^{2}$ UICC-TPCC, Institut für Pathologie, Charite, Charite Platz 1, 10118 , Berlin, Germany.

Received: 5 December 2013 Accepted: 6 December 2013

Published: 20 January 2014

\section{References}

1. Rüdiger $\mathrm{H}$, Gabius $\mathrm{H}$-J: The biochemical basis and coding capacity of the sugar code. In The Sugar Code. Fundamentals of glycosciences. Edited by Gabius H-J. Weinheim, Germany: Wiley-VCH; 2009:3-13.

2. Laine RA: The information-storing potential of the sugar code. In Glycosciences: Status and Perspectives. Edited by Gabius H-J, Gabius S. London - Weinheim: Chapman \& Hall; 1997:1-14.

3. Merzendorfer $\mathrm{H}$ : Chitin: structure, function and metabolism. In The Sugar Code. Fundamentals of glycosciences. Edited by Gabius H-J. Weinheim, Germany: Wiley-VCH; 2009:217-229.

4. Reuter $\mathrm{G}$, Gabius H-J: Eukaryotic glycosylation: whim of nature or multipurpose tool? Cell Mol Life Sci 1999, 55(3):368-422.

5. Buddecke E: Proteoglycans. In The Sugar Code. Fundamentals of glycosciences. Edited by Gabius H-J. Weinheim, Germany: Wiley-VCH; 2009:199-216.

6. Kopitz J: Glycolipids. In The Sugar Code. Fundamentals of glycosciences. Edited by Gabius H-J. Weinheim, Germany: Wiley-VCH; 2009:177-198.

7. Patsos G, Corfield A: O-Glycosylation: structural diversity and function. In The Sugar Code. Fundamentals of glycosciences. Edited by Gabius $\mathrm{H}-\mathrm{J}$. Weinheim, Germany: Wiley-VCH; 2009:111-137.

8. Zuber C, Roth J: N-Glycosylation. In The Sugar Code. Fundamentals of glycosciences. Edited by Gabius H-J. Weinheim, Germany: Wiley-VCH; 2009:87-110.

9. Spiro RG: Protein glycosylation: nature, distribution, enzymatic formation, and disease implications of glycopeptide bonds. Glycobiology 2002, 12(4):43R-56R

10. Gabius HJ, André S, Kaltner H, Siebert HC: The sugar code: functional lectinomics. Biochim Biophys Acta 2002, 1572(2-3):165-177.

11. Roseman S: Reflections on glycobiology. J Biol Chem 2001, 276(45):41527-41542. 
12. Nakagawa $\mathrm{H}$ : Analytical aspects: analysis of protein-bound glycans. In The Sugar Code. Fundamentals of glycosciences. Edited by Gabius H-J. Weinheim, Germany: Wiley-VCH; 2009:71-83.

13. Mechref $Y$, Hu Y, Garcia A, Hussein A: Identifying cancer biomarkers by mass spectrometry-based glycomics. Electrophoresis 2012, 33(12):1755-1767.

14. Galli C, Basso D, Plebani M: CA 19-9: handle with care. Clin Chem Lab Med 2013, 51(7):1369-1383.

15. Novotny MV, Alley WR Jr, Mann BF: Analytical glycobiology at high sensitivity: current approaches and directions. Glycoconj J 2013, 30(2):89-117.

16. Schrével J, Gros D, Monsigny M: Cytochemistry of cell glycoconjugates. Progr Histochem Cytochem 1981, 14(2):1-269.

17. Caselitz J: Lectins and blood group substances as "tumor markers". Curr Top Pathol 1987, 77:245-277.

18. Damjanov I: Lectin cytochemistry and histochemistry. Lab Invest 1987, 57(1):5-20.

19. Spicer SS, Schulte BA: Diversity of cell glycoconjugates shown histochemically: a perspective. J Histochem Cytochem 1992, 40:1-38.

20. Danguy A, Akif F, Pajak B, Gabius H-J: Contribution of carbohydrate histochemistry to glycobiology. Histol Histopathol 1994, 9:155-171.

21. Roth J: Lectins for histochemical demonstration of glycans. Histochem Cell Biol 2011, 136(2):117-130.

22. Schwarz HP, Dorner F: Karl Landsteiner and his major contributions to haematology. Br J Haematol 2003, 121(4):556-565.

23. Boyd WC: The lectins: their present status. Vox Sang 1963, 8:1-32.

24. Watkins WM: A half century of blood-group antigen research: some personal recollections. Trends Glycosci Glycotechnol 1999, 11:391-411.

25. Rüdiger H, Gabius H-J: The history of lectinology. In The Sugar Code. Fundamentals of glycosciences. Edited by Gabius H-J. Weinheim, Germany: Wiley-VCH; 2009:261-268.

26. Patsos G, André S, Roeckel N, Gromes R, Gebert J, Kopitz J, Gabius H-J: Compensation of loss of protein function in microsatellite-unstable colon cancer cells (HCT116): a gene-dependent effect on the cell surface glycan profile. Glycobiology 2009, 19(7):726-734.

27. van de Wouwer M, André S, Gabius H-J, Villalobo A: Nitric oxide changes distinct aspects of the glycophenotype of human neuroblastoma NB69 cells. Nitric Oxide 2011, 24(2):91-101.

28. Gebert J, Kloor M, Lee J, Lohr M, André S, Wagner R, Kopitz J, Gabius H-J: Colonic carcinogenesis along different genetic routes: glycophenotyping of tumor cases separated by microsatellite instability/stability. Histochem Cell Biol 2012, 138(2):339-350

29. Unverzagt C, André S, Seifert J, Kojima S, Fink C, Srikrishna G, Freeze H, Kayser K, Gabius H-J: Structure-activity profiles of complex biantennary glycans with core fucosylation and with/without additional a2,3/a2,6-sialylation: synthesis of neoglycoproteins and their properties in lectin assays, cell binding, and organ uptake. J Med Chem 2002, 45(2):478-491.

30. André S, Unverzagt C, Kojima S, Frank M, Seifert J, Fink C, Kayser K, von der Lieth C-W, Gabius H-J: Determination of modulation of ligand properties of synthetic complex-type biantennary $\mathrm{N}$-glycans by introduction of bisecting GICNAc in silico, in vitro and in vivo. Eur J Biochem 2004, 271(1):118-134.

31. André S, Kozár T, Schuberth R, Unverzagt C, Kojima S, Gabius H-J: Substitutions in the N-glycan core as regulators of biorecognition: the case of corefucose and bisecting GIcNAc moieties. Biochemistry 2007, 46:6984-6995.

32. André S, Kozár T, Kojima S, Unverzagt C, Gabius H-J: From structural to functional glycomics: core substitutions as molecular switches for shape and lectin affinity of $\mathrm{N}$-glycans. Biol Chem 2009, 390(7):557-565.

33. Takahashi M, Kuroki Y, Ohtsubo K, Taniguchi N: Core fucose and bisecting GlcNAc, the direct modifiers of the N-glycan core: their functions and target proteins. Carbohydr Res 2009, 344(12):1387-1390.

34. Gabius H-J, van de Wouwer M, André S, Villalobo A: Down-regulation of the epidermal growth factor receptor by altering $\mathrm{N}$-glycosylation: emerging role of $\beta 1$,4-galactosyltransferases. Anticancer Res 2012, 32(5):1565-1572.

35. Cooper DNW: Galectinomics: finding themes in complexity. Biochim Biophys Acta 2002, 1572:209-231.

36. Gready JN, Zelensky AN: Routes in lectin evolution: case study on the Ctype lectin-like domains. In The Sugar Code. Fundamentals of glycosciences. Edited by Gabius H-J. Weinheim, Germany: Wiley-VCH; 2009:329-346.

37. Pál Z, Antal P, Srivastava SK, Hullám G, Semsei AF, Gál J, Svébis M, Soós G, Szalai $C$, André $S$, et al: Non-synonymous single nucleotide polymorphisms in genes for immunoregulatory galectins: association of galectin-8 (F19Y) occurrence with autoimmune diseases in a Caucasian population. Biochim Biophys Acta 2012, 1820(10):1512-1518.
38. Kaltner $\mathrm{H}$, Gabius $\mathrm{H}-\mathrm{J}$ : A toolbox of lectins for translating the sugar code: the galectin network in phylogenesis and tumors. Histol Histopathol 2012, 27(4):397-416.

39. Kaltner H, Raschta A-S, Manning JC, Gabius H-J: Copy-number variation of functional galectin genes: Studying animal galectin-7 (p53-induced gene 1 in man) and tandem-repeat-type galectins-4 and -9. Glycobiology 2013, 23(10):1152-1163.

40. von der Lieth C-W, Siebert H-C, Kozár T, Burchert M, Frank M, Gilleron M, Kaltner H, Kayser G, Tajkhorshid E, Bovin NV, et al: Lectin ligands: new insights into their conformations and their dynamic behavior and the discovery of conformer selection by lectins. Acta Anat 1998, 161(1-4):91-109.

41. Gabius H-J, André S, Jiménez-Barbero J, Romero A, Solís D: From lectin structure to functional glycomics: principles of the sugar code. Trends Biochem Sci 2011, 36(6):298-313.

42. Gabius H-J: Animal and human lectins. In The Sugar Code. Fundamentals of glycosciences. Edited by Gabius H-J. Weinheim, Germany: Wiley-VCH; 2009:317-328.

43. Gabius H-J, Springer WR, Barondes SH: Receptor for the cell binding site of discoidin I. Cell 1985, 42:449-456.

44. Takahashi K, Ip WE, Michelow IC, Ezekowitz RA: The mannose-binding lectin: a prototypic pattern recognition molecule. Curr Opin Immunol 2006, 18(1):16-23.

45. Thiel S: Complement activating soluble pattern recognition molecules with collagen-like regions, mannan-binding lectin, ficolins and associated proteins. Mol Immunol 2007, 44(16):3875-3888.

46. Delacour D, Gouyer V, Zanetta J-P, Drobecq H, Leteurtre E, Grard G, Moreau-Hannedouche O, Maes E, Pons A, André S, et al: Galectin-4 and sulfatides in apical membrane trafficking in enterocyte-like cells. J Cell Biol 2005, 169(3):491-501.

47. Stechly L, Morelle W, Dessein AF, André S, Grard G, Trinel D, Dejonghe MJ, Leteurtre E, Drobecq H, Trugnan G, et al: Galectin-4-regulated delivery of glycoproteins to the brush border membrane of enterocyte-like cells. Traffic 2009, 10(4):438-450.

48. Kollmann K, Pohl S, Marschner K, Encarnacao M, Sakwa I, Tiede S, Poorthuis BJ, Lubke T, Muller-Loennies S, Storch S, et al: Mannose phosphorylation in health and disease. Eur J Cell Biol 2010, 89(1):117-123.

49. Velasco S, Díez-Revuelta N, Hernández-lglesias T, Kaltner H, André S, Gabius H-J Abad-Rodriguez J: Neuronal galectin-4 is required for axon growth and for the organization of axonal membrane L1 delivery and clustering. J Neurochem 2013, 125(1):49-62.

50. Reuter G, Gabius H-J: Sialic acids. Structure, analysis, metabolism, and recognition. Biol Chem Hoppe-Seyler 1996, 377:325-342.

51. André S, Sanchez-Ruderisch H, Nakagawa H, Buchholz M, Kopitz J, Forberich $P$, Kemmner W, Böck C, Deguchi K, Detjen KM, et al: Tumor suppressor p16 ${ }^{\text {INK4a }}$ : modulator of glycomic profile and galectin-1 expression to increase susceptibility to carbohydrate-dependent induction of anoikis in pancreatic carcinoma cells. FEBS J 2007, 274:3233-3256.

52. Sanchez-Ruderisch H, Fischer C, Detjen KM, Welzel M, Wimmel A, Manning JC, André S, Gabius H-J: Tumor suppressor p16 ${ }^{\mathrm{INK} 4 \mathrm{a}}$ : downregulation of galectin-3, an endogenous competitor of the pro-anoikis effector galectin1, in a pancreatic carcinoma model. FEBS J 2010, 277(17):3552-3563.

53. Amano M, Eriksson H, Manning JC, Detjen KM, André S, Nishimura S-I, Lehtiö J, Gabius H-J: Tumour suppressor p $16^{\mathrm{INK} 4 \mathrm{a}}$ : anoikis-favouring decrease in N/Oglycan/cell surface sialylation by down-regulation of enzymes in sialic acid biosynthesis in tandem in a pancreatic carcinoma model. FEBS J 2012, 279(21):4062-4080.

54. Kopitz J, von Reitzenstein C, Burchert M, Cantz M, Gabius H-J: Galectin-1 is a major receptor for ganglioside GM1, a product of the growthcontrolling activity of a cell surface ganglioside sialidase, on human neuroblastoma cells in culture. J Biol Chem 1998, 273(18):11205-11211.

55. Kopitz J, von Reitzenstein C, André S, Kaltner H, Uhl J, Ehemann V, Cantz M, Gabius $\mathrm{H}-\mathrm{J}$ : Negative regulation of neuroblastoma cell growth by carbohydrate-dependent surface binding of galectin-1 and functional divergence from galectin-3. J Biol Chem 2001, 276(38):35917-35923.

56. Wang J, Lu ZH, Gabius H-J, Rohowsky-Kochan C, Ledeen RW, Wu G: Cross-linking of GM1 ganglioside by galectin-1 mediates regulatory $T$ cell activity involving TRPC5 channel activation: possible role in suppressing experimental autoimmune encephalomyelitis. J Immuno/ 2009, 182(7):4036-4045.

57. Kopitz J, Bergmann M, Gabius H-J: How adhesion/growth-regulatory galectins- 1 and -3 attain cell specificity: case study defining their target on neuroblastoma cells (SK-N-MC) and marked affinity regulation by 
affecting microdomain organization of the membrane. IUBMB Life 2010, 62(8):624-628.

58. Wu G, Lu ZH, Gabius H-J, Ledeen RW, Bleich D: Ganglioside GM1 deficiency in effector $\mathrm{T}$ cells from NOD mice induces resistance to regulatory T cell suppression. Diabetes 2011, 60(9):2341-2349.

59. Gabius H-J, Engelhardt R, Rehm S, Cramer F: Biochemical characterization of endogenous carbohydrate-binding proteins from spontaneous murine rhabdomyosarcoma, mammary adenocarcinoma, and ovarian teratoma. J Natl Cancer Inst 1984, 73:1349-1357.

60. Gabius H-J, Engelhardt R, Cramer F, Bätge R, Nagel GA: Pattern of endogenous lectins in a human epithelial tumor. Cancer Res 1985, 45:253-257.

61. Gabius H-J: Glycobiomarkers by glycoproteomics and glycan profiling (glycomics): emergence of functionality. Biochem Soc Trans 2011, 39(1):399-405.

62. Smetana $\mathrm{K} \mathrm{Jr}$, André S, Kaltner H, Kopitz J, Gabius H-J: Context-dependent multifunctionality of galectin-1: a challenge for defining the lectin as therapeutic target. Expert Opin Ther Targets 2013, 17(4):379-392.

63. Oscarson S: The chemist's way to synthesize glycosides. In The Sugar Code. Fundamentals of glycosciences. Edited by Gabius H-J. Weinheim, Germany: Wiley-VCH; 2009:31-51.

64. Stowell CP, Lee YC: Neoglycoproteins: the preparation and application of synthetic glycoproteins. Adv Carbohydr Chem Biochem 1980, 37:225-281.

65. Aplin JD, Wriston JC Jr: Preparation, properties and applications of carbohydrate conjugates of proteins and lipids. CRC Crit Rev Biochem 1981, 10:259-306.

66. Gabius H-J, Gabius S, Zemlyanukhina TV, Bovin NV, Brinck U, Danguy A, Joshi SS, Kayser K, Schottelius J, Sinowatz F, et al: Reverse lectin histochemistry: design and application of glycoligands for detection of cell and tissue lectins. Histol Histopathol 1993, 8(2):369-383.

67. Lee YC, Lee RT (Eds): Neoglycoconjugates. Preparation and Applications. San Diego: Academic; 1994

68. Hardonk MJ, Scholtens HB: A histochemical study about the zonal distribution of the galactose-binding protein in rat liver. Histochemistry 1980, 69:289-297.

69. Straus W: Cytochemical detection of mannose-specific receptors for glycoproteins with horseradish peroxidase as a ligand. Histochemistry 1981, 73:39-47.

70. Straus W, Keller JM: Unusual binding sites for horseradish peroxidase on the surface of cultured and isolated mammalian cells. Suppression of binding by certain nucleotides and glycoproteins, and a role for calcium. Histochemistry 1986, 85(4):277-285.

71. Gabius H-J, Engelhardt R, Hellmann K-P, Hellmann T, Ochsenfahrt A: Preparation of neoglycoprotein-enzyme conjugate using a heterobifunctional reagent and its use in solid-phase assay and histochemistry. Anal Biochem 1987, 165:349-355.

72. Gabius S, Hellmann KP, Hellmann T, Brinck U, Gabius H-J: Neoglycoenzymes: a versatile tool for lectin detection in solid-phase assays and glycohistochemistry. Anal Biochem 1989, 182:447-451.

73. André S, Kopitz J, Kaltner H, Villalobo A, Gabius H-J: Glycans as functional markers in malignancy? In The Sugar Code. Fundamentals of glycosciences. Edited by Gabius H-J. Weinheim, Germany: Wiley-VCH; 2009:419-432.

74. Bardosi A, Dimitri T, Gabius H-J: (Neo)glycoproteins as tools in neuropathology: histochemical patterns of the extent of expression of endogenous carbohydrate-binding receptors, like lectins, in meningiomas. Virchows Arch [Cell Pathol] 1988, 56:35-43.

75. Gabius H-J, Bodanowitz S, Schauer A: Endogenous sugar-binding proteins in human breast tissue and benign and malignant breast lesions. Cancer 1988, 61:1125-1131.

76. Kayser K, Gabius HJ, Ciesiolka T, Ebert W, Bach S: Histopathologic evaluation of application of labeled neoglycoproteins in primary bronchus carcinoma. Hum Pathol 1989, 20(4):352-360.

77. Danguy A, Kayser K, Bovin NV, Gabius H-J: The relevance of neoglycoconjugates for histology and pathology. Trends Glycosci Glycotechnol 1995 7:261-275

78. Kayser K, Böhm G, Blum S, Beyer M, Zink S, André S, Gabius H-J: Glyco- and immunohistochemical refinement of the differential diagnosis between mesothelioma and metastatic carcinoma and survival analysis of patients. J Pathol 2001, 193:175-180.

79. Kayser K, Kayser C, Rahn W, Bovin NV, Gabius H-J: Carcinoid tumors of the lung: immuno- and ligandohistochemistry, analysis of integrated optical density, syntactic structure analysis, clinical data, and prognosis of patients treated surgically. J Surg Oncol 1996, 63:99-106.
80. Gabius H-J, Schröter C, Gabius S, Brinck U, Tietze L-F: Binding of T-antigenbearing neoglycoprotein and peanut agglutinin to cultured tumor cells and breast carcinomas. J Histochem Cytochem 1990, 38:1625-1631.

81. Kayser K, Bovin NV, Korchagina EY, Zeilinger C, Zeng F-Y, Gabius H-J: Correlation of expression of binding sites for synthetic blood group $\mathrm{A}_{-}, \mathrm{B}-$, and $\mathrm{H}$-trisaccharides and for sarcolectin with survival of patients with bronchial carcinoma. Eur J Cancer 1994, 30A(5):653-657.

82. Wu AM, Wu JH, Liu J-H, Singh T, André S, Kaltner H, Gabius H-J: Effects of polyvalency of glycotopes and natural modifications of human blood group $A B H / L e w i s$ sugars at the Gal $\beta 1$-terminated core saccharides on the binding of domain-I of recombinant tandem-repeat-type galectin-4 from rat gastrointestinal tract (G4-N). Biochimie 2004, 86:317-326.

83. Krzeminski M, Singh T, André S, Lensch M, Wu AM, Bonvin AMJJ, Gabius H-J: Human galectin-3 (Mac-2 antigen): defining molecular switches of affinity to natural glycoproteins, structural and dynamic aspects of glycan binding by flexible ligand docking and putative regulatory sequences in the proximal promoter region. Biochim Biophys Acta 2011, 1810(2):150-161.

84. Bardosi A, Dimitri T, Wosgien B, Gabius H-J: Expression of endogenous receptors for neoglycoproteins, especially lectins, which allow fiber typing on formaldehyde-fixed, paraffin-embedded muscle biopsy specimens. A glycohistochemical, immunohistochemical and glycobiochemical study. J Histochem Cytochem 1989, 37:989-998.

85. Gabius H-J, Brehler R, Schauer A, Cramer F: Localization of endogenous lectins in normal human breast, benign breast lesions and mammary carcinomas. Virch Arch [Cell Pathol] 1986, 52(2):107-115.

86. Nagy N, Bronckart Y, Camby I, Legendre H, Lahm H, Kaltner H, Hadari Y, Van Ham P, Yeaton P, Pector J-C, et al: Galectin-8 expression decreases in cancer compared with normal and dysplastic human colon tissue and acts significantly on human colon cancer cell migration as a suppressor. Gut 2002, 50(3):392-401.

87. Nagy N, Legendre H, Engels O, André S, Kaltner H, Wasano K, Zick Y, Pector J-C, Decaestecker C, Gabius H-J, et al: Refined prognostic evaluation in colon cancer using immunohistochemical galectin fingerprinting. Cancer 2003, 97:1849-1858.

88. Saussez S, Cucu D-R, Decaestecker C, Chevalier D, Kaltner H, André S, Wacreniez A, Toubeau G, Camby I, Gabius H-J, et al: Galectin-7 (p53-induced gene-1): a new prognostic predictor of recurrence and survival in stage IV hypopharyngeal cancer. Ann Surg Oncol 2006, 13:999-1009.

89. Cludts S, Decaestecker C, Mahillon V, Chevalier D, Kaltner H, André S, Remmelink M, Leroy X, Gabius H-J, Saussez S: Galectin-8 up-regulation during hypopharyngeal and laryngeal tumor progression and comparison with galectins-1, -3 and -7. Anticancer Res 2009, 29(12):4933-4940.

90. Langbein S, Brade J, Badawi JK, Hatzinger M, Kaltner H, Lensch M, Specht K, André $S$, Brinck $U$, Alken $P$, et al: Gene-expression signature of adhesion/ growth-regulatory tissue lectins (galectins) in transitional cell cancer and its prognostic relevance. Histopathology 2007, 51(5):681-690.

91. Saussez S, de Leval L, Decaestecker C, Sirtaine N, Cludts S, Duray A, Chevalier D, André S, Gabius H-J, Remmelink M, et al: Galectin fingerprinting in Warthin's tumors: lectin-based approach to trace its origin? Histol Histopathol 2010, 25(5):541-550.

92. Remmelink M, de Leval L, Decaestecker C, Duray A, Crompot E, Sirtaine N, André S, Kaltner H, Leroy X, Gabius H-J, et al: Quantitative immunohistochemical fingerprinting of adhesion/growth-regulatory galectins in salivary gland tumours: divergent profiles with diagnostic potential. Histopathology 2011, 58(4):543-556.

93. Kayser K, Gabius H-J: Graph theory and the entropy concept in histochemistry. Theoretical considerations, application in histopathology and the combination with receptor-specific approaches. Progr Histochem Cytochem 1997, 32(2):1-106.

94. Kayser K, Gabius H-J: The application of thermodynamic principles to histochemical and morphometric tissue research: principles and practical outline with focus on glycosciences. Cell Tissue Res 1999, 296:443-455.

95. Kayser K, Höft D, Hufnagl P, Caselitz J, Zick Y, André S, Kaltner H, Gabius H-J: Combined analysis of tumor growth pattern and expression of endogenous lectins as a prognostic tool in primary testicular cancer and its lung metastases. Histol Histopathol 2003, 18:771-779.

96. Gabius H-J, Wosgien B, Brinck U, Schauer A: Localization of endogenous $\beta$-galactoside-specific lectins by neoglycoproteins, lectin-binding tissue glycoproteins and antibodies and of accessible lectin-specific ligands by a mammalian lectin in human breast cancer. Pathol Res Pract 1991, 187(7):839-847. 
97. Purkrábková T, Smetana K Jr, Dvoránková B, Holíková Z, Böck C, Lensch M, André S, Pytlík R, Liu F-T, Klíma J, et al: New aspects of galectin functionality in nuclei of cultured bone marrow stromal and epidermal cells: biotinylated galectins as tool to detect specific binding sites. Biol Cell 2003, 95:535-545.

98. Saal I, Nagy N, Lensch M, Lohr M, Manning JC, Decaestecker C, André S, Kiss R, Salmon I, Gabius H-J: Human galectin-2: expression profiling by RT-PCR/immunohistochemistry and its introduction as histochemical tool for ligand localization. Histol Histopathol 2005, 20:1191-1208.

99. Habermann FA, André S, Kaltner H, Kübler D, Sinowatz F, Gabius H-J: Galectins as tools for glycan mapping in histology: comparison of their binding profiles to the bovine zona pellucida by confocal laser scanning microscopy. Histochem Cell Biol 2011, 135(6):539-552.

100. Kodet O, Dvoránková B, Lacina L, André S, Kaltner H, Gabius H-J, Smetana K Jr: Comparative analysis of nuclear presence of adhesion/growth-regulatory galectins and galectin reactivity in interphasic and mitotic cells. Folia Biol (Praha) 2011, 57:125-132.

101. Schlötzer-Schrehardt U, André S, Janko C, Kaltner H, Kopitz J, Gabius H-J, Herrmann M: Adhesion/growth-regulatory galectins in the human eye: localization profiles and tissue reactivities as a standard to detect disease-associated alterations. Graefes Arch Clin Exp Ophthalmol 2012, 250(8):1169-1180.

102. Plzák J, Betka J, Smetana K Jr, Chovanec M, Kaltner H, André S, Kodet R, Gabius H-J: Galectin-3: an emerging prognostic indicator in advanced head and neck carcinoma. Eur J Cancer 2004, 40(15):2324-2330.

103. Dawson H, André S, Karamitopoulou E, Zlobec I, Gabius H-J: The growing galectin network in colon cancer and clinical relevance of cytoplasmic galectin-3 reactivity. Anticancer Res 2013, 33(8):3053-3059.

104. Kopitz J, Ballikaya S, André S, Gabius H-J: Ganglioside GM1/galectindependent growth regulation in human neuroblastoma cells: special properties of bivalent galectin-4 and significance of linker length for ligand selection. Neurochem Res 2012, 37(6):1267-1276.

105. Kopitz J, Fík Z, André S, Smetana K Jr, Gabius H-J: Single-site mutational engineering and following monoPEGylation of the human lectin galectin-2: effects on ligand binding, functional aspects, and clearance from serum. Mol Pharmaceut 2013, 10(5):2054-2061.

106. Fischer C, Sanchez-Ruderisch H, Welzel M, Wiedenmann B, Sakai T, André S, Gabius H-J, Khachigian L, Detjen K, Rosewicz S: Galectin-1 interacts with the $\alpha_{5} \beta_{1}$ fibronectin receptor to restrict carcinoma cell growth via induction of p21 and p27. J Biol Chem 2005, 280:37266-37277.

107. Sanchez-Ruderisch H, Detjen KM, Welzel M, André S, Fischer C, Gabius H-J, Rosewicz S: Galectin-1 sensitizes carcinoma cells to anoikis via the fibronectin receptor $a_{5} \beta_{1}$-integrin. Cell Death Differ 2011, 18(5):806-816.

108. Rappl G, Abken H, Muche JM, Sterry W, Tilgen W, André S, Kaltner H, Ugurel $\mathrm{S}$, Gabius H-J, Reinhold U: $\mathrm{CD}^{+} \mathrm{CD}^{-}$leukemic T cells from patients with Sézary syndrome are protected from galectin-1-triggered T cell death. Leukemia 2002, 16(5):840-845.

109. Kayser K, Märkle C, Kugler C, André S, Schüring M-P, Zeng F-Y, Gabius H-J: Integrated nuclear fluorescence and expression of hormone-binding sites in malignant pleural effusions. Anal Quant Cytol Histol 2000, 22:364-372.

110. Kayser K, Gabius H-J, Köhler A, Runtsch T: Binding of neuroendocrine markders and biotinylated sex hormones and the survival $\mathrm{n}$ human lung cancer. Lung Cancer 1990, 6:171-183.

111. Kayser K, Kayser G, André S, Altiner M, Gabius H-J: Evaluation of histochemical anthracyclin binding as potential prognostic parameter in small cell lung cancer. Oncol Rep 1999, 6:1153-1157.

112. Kayser K, Bubenzer J, Kayser G, Eichhorn S, Zemlyanukhina TV, Bovin NV, André S, Koopmann J, Gabius H-J: Expression of lectin-, interleukin-2-, and histo-blood group-binding sites in prostate cancer and its correlation to integrated optical density and syntactic structure analysis. Analyt Quant Cytol Histol 1995, 17:135-142.

113. Kayser K, Nwoye JO, Kosjerina S, Goldmann T, Vollmer E, Kaltner H, André S, Gabius H-J: Atypical adenomatous hyperplasia of lung: its incidence and analysis of clinical, glycohistochemical and structural features including newly defined growth regulators and vascularization. Lung Cancer 2003, 42:171-182.

114. Kayser K, Gabius HJ: Analysis of expression of erythropoietin-binding sites in human lung carcinoma by the biotinylated ligand. Zentralb/ Pathol 1992, 138(4):266-270.

115. Kayser K, Weisse G, Gabius HJ, Bubenzer J, von Eberstein M, Hintze T: Differentiation-related expression of epidermal growth factor receptors in human lung carcinoma demonstrated histochemically by biotinylated epidermal growth factor. Mod Pathol 1990, 3(3):327-331.

116. Kayser K, Weisse G, Gabius HJ, Hintze T: Biotinylated epidermal growth factor: a useful tool for the histochemical analysis of specific binding sites. Histochem J 1990, 22(8):426-432.

117. Zeng F-Y, Weiser WY, Kratzin H, Stahl B, Karas M, Gabius H-J: The major binding protein of the interferon antagonist sarcolectin in human placenta is a macrophage migration inhibitory factor. Arch Biochem Biophys 1993, 303:74-80.

118. Zeng F-Y, Gerke V, Gabius H-J: Characterization of the macrophage migration inhibitory factor-binding site of sarcolectin and its relationship to human serum albumin. Biochem Biophys Res Commun 1994, 200(1):89-94.

doi:10.1186/1746-1596-9-4

Cite this article as: Gabius and Kayser: Introduction to glycopathology: the concept, the tools and the perspectives. Diagnostic Pathology 2014 9:4.

\section{Submit your next manuscript to BioMed Central and take full advantage of:}

- Convenient online submission

- Thorough peer review

- No space constraints or color figure charges

- Immediate publication on acceptance

- Inclusion in PubMed, CAS, Scopus and Google Scholar

- Research which is freely available for redistribution

Submit your manuscript at www.biomedcentral.com/submit
C Biomed Central 